\title{
Transformation of Educational Quality Assurance Concepts and Practices to Reduce the Gap in School Self-Evaluation Results With Accreditation Evidence From Indonesia
}

\author{
Roni Indra*, Aan Komariah, Taufani C. Kurniatun \\ Educational Administration Program \\ Universitas Pendidikan Indonesia \\ Bandung, Indonesia \\ *roni.indra@upi.edu
}

\begin{abstract}
This study aims to describe the concept and practice of quality assurance of primary and secondary education in Indonesia with a focused on school self-evaluation and accreditation. This research used quantitative and qualitative approaches. The data used are secondary data of the national quality mapping, and the primary data was collected through questionnaires and in depth-interview. The analysis used is interpretive with the aim of the extent of the gap in the quality report cards and school accreditation scores. The results of the study show that both have a reciprocal and integral relationship.
\end{abstract}

Keywords-accreditation, national education standards, quality assurance system, school self-evaluation

\section{INTRODUCTION}

In Indonesia, the quality of education refers to the eight standards set out in the Government Regulation of the Republic of Indonesia Number 19 of 2005 and its amendments to the National Education Standards. Eight national education standards are grouped into three education components, namely input, process, and output $[1,2]$. The input component consists of teacher standards and educational staff; facilities and infrastructure; management; financing. Process components consist of content standards; process; assessment. The output component consists of the competency standards of graduates or student achievements. When the level of conformity of education delivery with the eight national education standards is higher, the education provision is said to have been of national quality.

The level of conformity is evaluated through two approaches, namely school self-evaluation (internal) and external evaluation/accreditation (external). These two approaches are school-based evaluations. This evaluation is carried out to improve and enhance the quality of education at the school, regional, and national levels. Internal and external evaluations have a reciprocal and integral relationship [3] so that the two cannot be separated [4-6], because they are both oriented towards improving quality and accountability $[7,8]$.

Many countries have implemented education quality assurance and improvement through school-based evaluations especially through the school self-evaluation approach, such as European countries [9-12], and even countries in Asia, such as Hong Kong, China, and Singapore [13-15] and Indonesia. Besides, to measure and ensure compliance with quality standards in schools, an external party is also examined by an appointed body or authority such as the Office for Standards in Education (Ofsted) in England [16], General Inspection of Education and Science in Portugal [8], School Inspectorate in Sweden [17], and other external authorities (external officials commissioned) [18]. This authority carries out periodic inspections and justifies compliance with established quality standards [7]. In Indonesia, the authority referred to in this case is called the National Accreditation Agency for Schools/Madrasahs (NAA-S/M)

In conducting school-based evaluations, internal (school) and external (accreditation) parties use the same quality reference, namely the eight national education standards. However, the development of indicators into sub-indicators or components of quality between the two parties is different. The instrument development team of each party has different perspectives in measuring school performance for quality assurance and improvement. These differences may lead to significantly different results and can even be contradictory. A study conducted by Vanhoof and Petegem in Belgium found a difference in assessment between internal and external [19]. These results differ from previous studies, where they suggested a similar trend between internal and external evaluation results [20].

The results of this study are interesting to study further, especially in the Indonesian context. Concerning benchmarks for the quality of education in Indonesia, which are eight 
national education standards, the results obtained in school self-evaluation and accreditation should have the same tendency. The minimum gap that occurs is not too significant. To strengthen the results, a description of the concepts and practices that occurred in Indonesia was conducted.

\section{SCHOOL SELF-EvaluATION}

\section{A. SEE Version 2009}

School self-evaluation in Indonesia was introduced along with the existence of school-based management policies mandated in Law Number 20 of 2003 concerning the National Education System. This policy is further elaborated through Government Regulation No. 19 of 2005, in which the management of education units at the primary and secondary education levels must apply school-based management. Then, starting in 2009, school self-evaluation was officially enforced following the issuance of the Minister of National Education Regulation Number 63 of 2009 concerning the Education Quality Assurance System (EQAS) which has the main function of improving the quality of education

Two priority things to do for that are School Self Evaluation (SSE) and School Monitoring by Local Government (SMLG). SMLG is part of the external party evaluation. This monitoring is carried out by the Regional Government (especially the Education Office and the Ministry of Religion Office) on the overall school performance in achieving quality standards. The monitoring results form the basis for planning and further corrective actions at the local level, and for their aggregation at the national level.

SSE is an important part of EQAS and is a component of data sources to improve quality. School self-evaluation is an internal school evaluation based on The Minimum Standards of Education Service (MSES) and National Standards of Education (NSE). School self-evaluation functions in building a national education information system, especially in photographing school performance. This information is then used for planning and education development at the regional and national levels. The relationship between SSE in EQAS according to the Minister of National Education Regulation Number 63 of 2009 can be seen in the Figure 1:

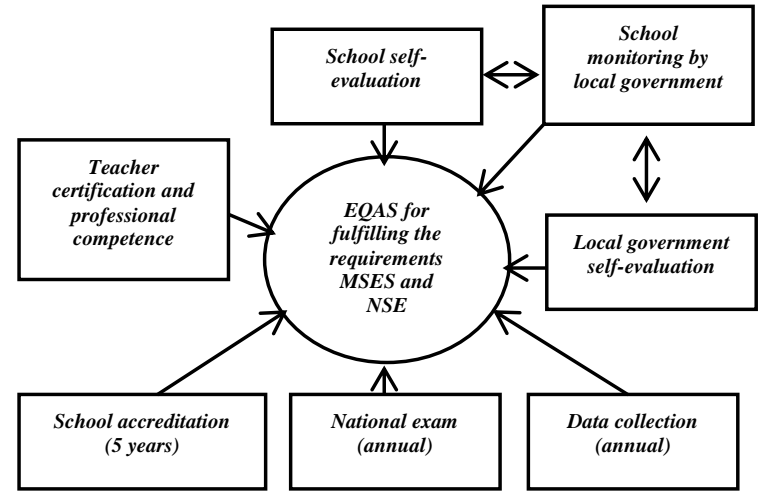

Fig. 1. SEE in EQAS.
School self-evaluation is carried out by the School Development Team (SDT) which is formed and determined by the School Principal. This team consists of representatives from teachers and education personnel, school committees, parents, school supervisors, and other representatives from community groups deemed worthy of being involved. This team together with the principal and supervisors of the supervising school filled out the instrument provided as well as collected evidence and information from various sources to assess school performance based on the indicators formulated in the instrument.

The SSE instrument consists of 8 (eight) national education standards which are translated into 26 components and 62 indicators. Each standard consists of many components that refer to each of the national education standards as the basis for schools to obtain qualitative performance information. Each component consists of several indicators that provide an overall picture of the component in question.

To ensure that the information provided is truly accurate and by school conditions, a data triangulation process is carried out through checking between quantitative and qualitative data; stakeholder opinions and assessments; and observation of the actual situation. Specifically, for the teaching and learning process, qualitative and quantitative information as a result of direct observation is carried out by including the followings in class for one full day; observing lessons; recording on video how to teach themself; classroom exchange between teachers; and observation among teachers.

After obtaining accurate information, the school fills in the available rubric to see the position of the stages of achievement. There are four stages of school achievement, namely Stage 1, not meeting the MSES. At this stage school performance has many weaknesses and requires a lot of improvement; 2nd stage meets MSES. At this stage, there are several strengths and weaknesses but still desperately need improvement; 3rd stage meets NSE. At this stage, school performance is good, but still needs improvement; 4th stage, surpassing NSE. At this stage, the school's performance is very good, exceeding the established standards.

After the information has been collected accurately, the SDT conducts a SWOT analysis to identify and prioritize areas requiring attention, which will then form the basis for school development plans. The school development plan contains a small number of priority improvements and can be managed by schools with predetermined outcomes and focuses on improving and achieving learning outcomes. This plan is then contained in a four-year plan and an annual plan to be implemented as part of a program to improve the quality of education in schools. The results of the program implementation are then monitored and the progress is reanalysed. The result is used as a portrait of school performance. 
This activity then becomes a cycle in SSE, as shown in the Figure 2:

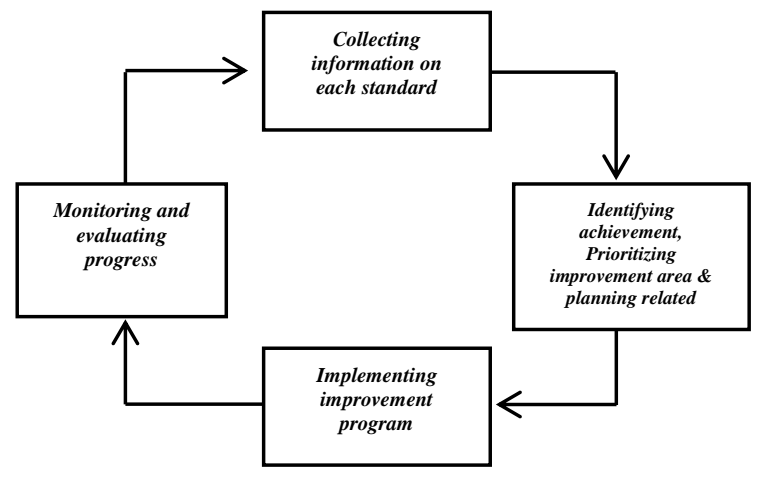

Fig. 2. A cycle of improvement and development school [21,22].

\section{B. SEE Version 2016}

In 2016, the concept of SSE changed, by the policy of the Minister of Education and Culture through regulation number 28 of 2016 concerning the Basic and Secondary Education Quality Assurance System (BS-EQAS). With this policy, the SSE concept is increasingly refined as a quality assurance system framework and its scope is emphasized at the primary and secondary education levels, as Figure 3:

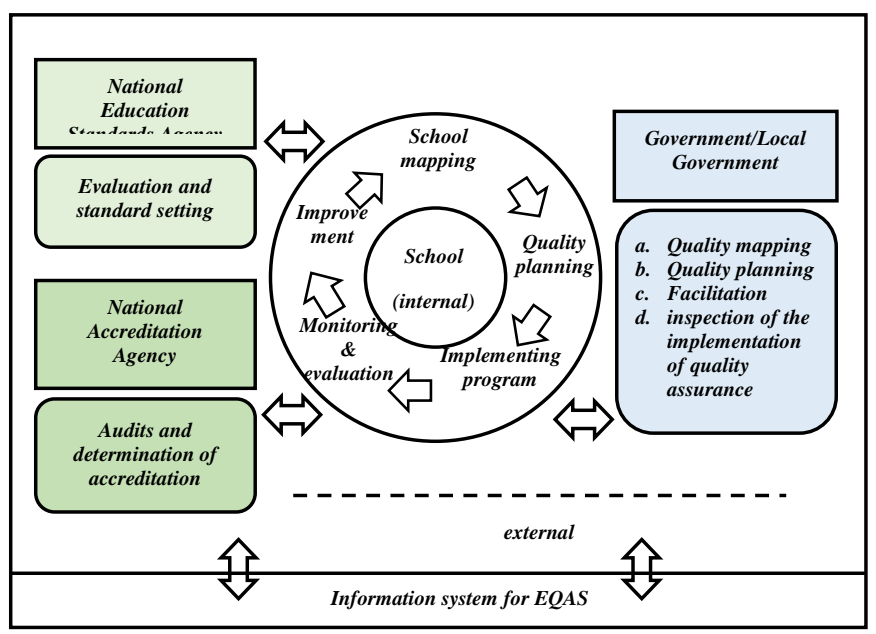

Fig. 3. A cycle of improvement and development school [21].

This system functions as a controller of the quality of education at the school, regional, and national levels, with the aim of at least meeting the NSE that have been set nationally. The higher the level of school achievement that is controlled in meeting the NSE, it can be said that the closer to the expectation of a quality school. Quality schools can be created through the implementation of good quality assurance by referring to the specified standards [22,23]. A quality school is characterized as a school that always makes continuous quality improvements in all fields with the main target is to improve a positive school climate to produce more than just student academic and non-academic achievement but also the quality of learning $[24,25]$.
BS-EQAS consists of internal and external systems. The internal system is the same as the practice of SSE, while the external system includes three roles and functions, namely the assessment of the conformity of NSE achievements in the form of accreditation carried out by the National Accreditation Agency for Schools/Madrasahs (NAA-S/M), evaluation and setting of NSE by the National Education Standards Agency, and facilitation or support for the implementation of the internal system by the government and the local government. The development of these two systems is supported by an education quality information system which includes eight NSE.

The Internal Quality Assurance System (IQAS) and the External Quality Assurance System (ExQAS) work in sharing roles among education stakeholders to ensure the quality of education continues to improve. This effort starts at the school level through school evaluation. This evaluation concept is categorized as a phase of check or measurement in the education quality assurance system [10]. On the one hand, school self-evaluation is related to the extent to which the school's performance or self-improvement efforts have been made (at least it meets NSE); and see how a portrait of educational achievement or quality maps. On the other hand, external school evaluation is related to the extent to which the Ministry of Education and Culture (MoEC) and the autonomous institutions under it, local governments, and other stakeholders have made a positive contribution to efforts to improve school quality; and what are the results of school accreditation carried out by the NAA-S/M.

SSE is part of the IQAS. This system has a cycle of activities that are interconnected and continuous, as can be seen in the Figure 4:

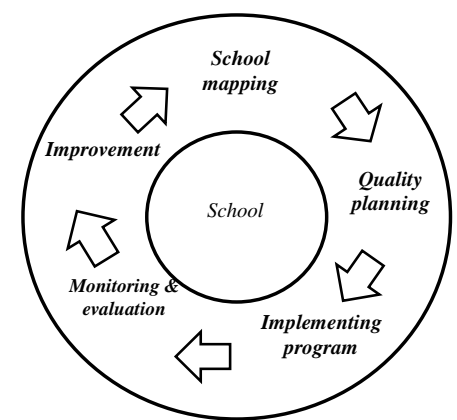

Fig. 4. Education quality assurance system [21].

This cycle is different from the previously established SSE cycle, where the initial process of providing school quality information in this cycle was carried out through mapping. This mapping concept is then used more in the quality assurance process. Besides, in this version there are five cycles of activities carried out by schools, namely, 1) conduct quality mapping based on eight NSE. From the map of school quality achievement then analyse the problem to produce recommendations for improvement; 2) making a plan of improvement as outlined in the schoolwork plan; 3 ) carry out improvements by the plan; 4) monitoring and evaluating the 
improvement process, and 5) formulating a follow-up strategy for improvement and quality improvement based on the results of monitoring and evaluation that have been carried out.

Quality mapping is carried out by schools by filling in the instruments provided by the development team (MoEC) through electronic (online) and conventional (offline) media. The technique of filling instruments with electronics requires device readiness such as applications, computers, networks. Whereas with conventional techniques, instrument sheets are distributed to respondents to be filled in completely. The quality mapping instrument in this version consists of 8 (eight) NSE, broken down into 29 indicators, and 189 sub-indicators. From this sub-indicator, it is then detailed again to the item questions. When compared with the previous instrument, this version is of course in greater quantity, but in quality, it can provide a comprehensive picture of the sub-indicators in question. Even so, the development team continued to evaluate and improve the instrument.

The instrument that has been filled in by the respondent is then verified and validated by the school supervisor. Validated data is sent to the Education Quality Information System server which is managed by the online development team for data processing into information on school quality achievement based on national standards. After the data is processed, schools can see the results in the form of quality reports.

The school quality achievement consists of five categories, each of which is limited in the lower-upper limit, and is characterized by an asterisk according to its color; as shown in Table 1:

TABLE I. CATEGORY OF QUALITY REPORT [23]

\begin{tabular}{|c|c|c|}
\hline Mark & Category & Average value \\
\hline$\star$ & To NSE-1 & $0-2.04$ \\
\hline$\star \star$ & To NSE-2 & $2.05-3.7$ \\
\hline$\star \star \star$ & To NSE-3 & $3.71-5.06$ \\
\hline$\star \star \star \star$ & To NSE-4 & $5.07-6.66$ \\
\hline$\star \star \star \star \star$ & Meets NSE & $6.67-7.00$ \\
\hline
\end{tabular}

With the availability of quality report cards, the school analyses the conditions and needs to provide recommendations for improvements that will be presented in the school work plan. Furthermore, the school goes through all activities in the IQAS cycle. The results of the application of the IQAS are used as; the basis for government or local government to provide resource support to schools; reference for NAA-S/M to carry out accreditation; and materials for evaluating the development of NSE. By using the results of the application of IQAS by external parties, it provides opportunities for schools to stimulate the implementation of IQAS well, develop, and legitimize its validity [6].

\section{METHODS}

This research used quantitative and qualitative approaches. The data used is secondary data from the results of the 2018 education quality mapping conducted by the Directorate General of Primary and Secondary Education, Ministry of Education and Culture. Primary data collection was carried out through questionnaires and in depth-interview with school principals and school's teams for internal quality assurance in 6 piloting schools (elementary and secondary schools) implementing the internal quality assurance system in Tanjungpinang City, Riau Islands Province. The analysis used is interpretive with the aim of developing an initial understanding to identify and measure the extent of the gaps in the results of school quality report and accreditation scored

\section{QuALITY MAPPING RESUlTs}

Based on the results of the 2018 education quality mapping, the level of achievement of the quality of education nationally is at level 4 Towards NSE. The following is a school quality report card at the basic (Elementary/SD \& Junior High School/SMP) and secondary (Senior High School/SMA \& Vocational School/SMK) levels of education:

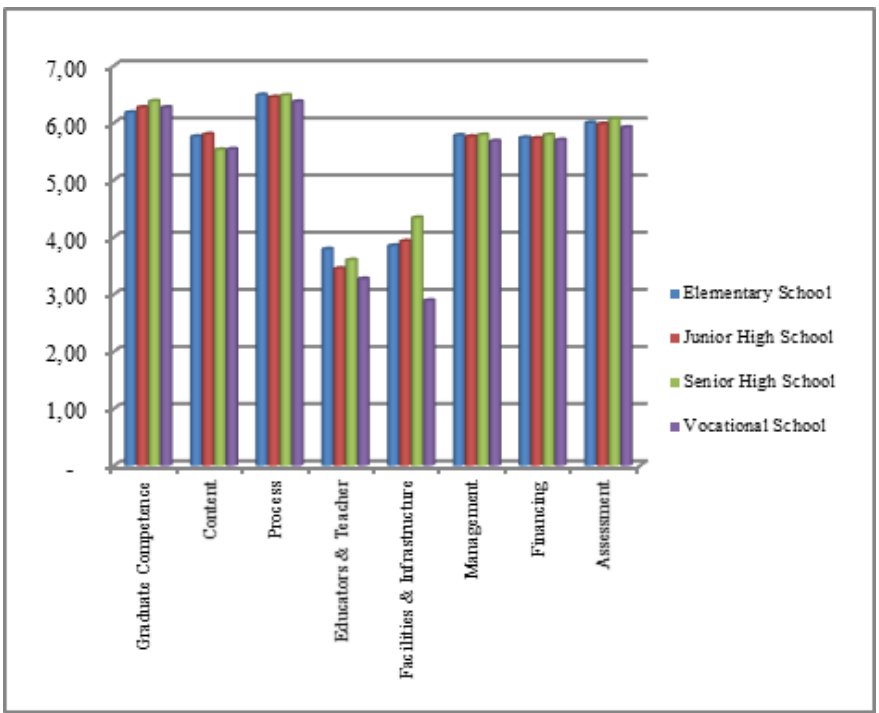

Fig. 5. Quality Report on each standard based on IQAS.

From the Figure 5, the average score for Elementary School is 5.41; Junior High School 5.38; Senior High School 5.46; and Vocational School 5.17. The school achievement category at all levels between the scores of 5.07-6.66. That is, it takes 'a little more' of quality improvement efforts to encourage the achievement of scores in the category of meeting the national education standards (6.67-7.00). But of course, it's not that easy. Elaboration is needed between schools through their autonomy, government and local governments through their authorities, as well as education stakeholders through their functions to improve quality together.

The data above shows that of the eight NSE, the lowest achievement is in the standards of educators and education 
personnel. At the SD level the achievement score of 3.79 is at level 3 Towards NSE, meanwhile for the SMP, SMA, and SMK the achievement category is even at level 2. This figure shows in general the availability and competence of educators and education personnel in some schools in Indonesia. Indonesia has not complied with the provisions. In the standards of educators and education personnel, there are five quality indicators, namely those related to availability and competence: teachers, school principals, administrative staff, laboratory assistants, and librarians by the provisions. Availability is related to quantity, while competence is related to quality.

When compared with the results of the latest SSE-based quality mapping conducted in 2013, based on the results of calculations using weighting standards and indicators against six national standards (except for infrastructure and facilities standards, and financing standards), the SD level quality achievement was 5.94, with the lowest achievement. in the graduate competency standard (5.05), and the process standard (5.49), while the standard achievement of educators and education personnel was 6.44. Meanwhile, for the junior high school level, the quality achievement was 6.22 , with the lowest achievement in the competency standards of graduates (4.95) and process standards (5.50), while the standard achievements of educators and education personnel were 6.49.

This figure shows that in general, the learning process in some schools in Indonesia has not been going well. In the process standard at that time, there were five components and nine quality indicators. The five components are related to the syllabus, lesson plans, learning resources, implemented learning, and supervision and evaluation of the learning process. In this case, the quality of learning and the learning climate in the classroom is certainly influenced by the ability of teachers to manage the class. Teachers who can do this are teachers who have the required competencies. Thus, the achievement of meeting the teacher competency standards from the previous evaluations was still low.

Moving on to the results of the external evaluation (school accreditation) as internal comparative data. In the 2019 Executive Summary document published by the NAB S/M, it is also found that the achievement of education standards and education personnel is relatively low for all levels of education. Based on the data, it is suggested that the comparison of the achievement of the NSE between 2014 and 2019 for SD, SMP, SMA, and SMK is equivalent. The results of the 2019 accreditation used as a comparison with 2014 are re-accredited schools/madrasahs (once every 5 years). The highest score for accreditation is 100 . The comparison is presented as follows:

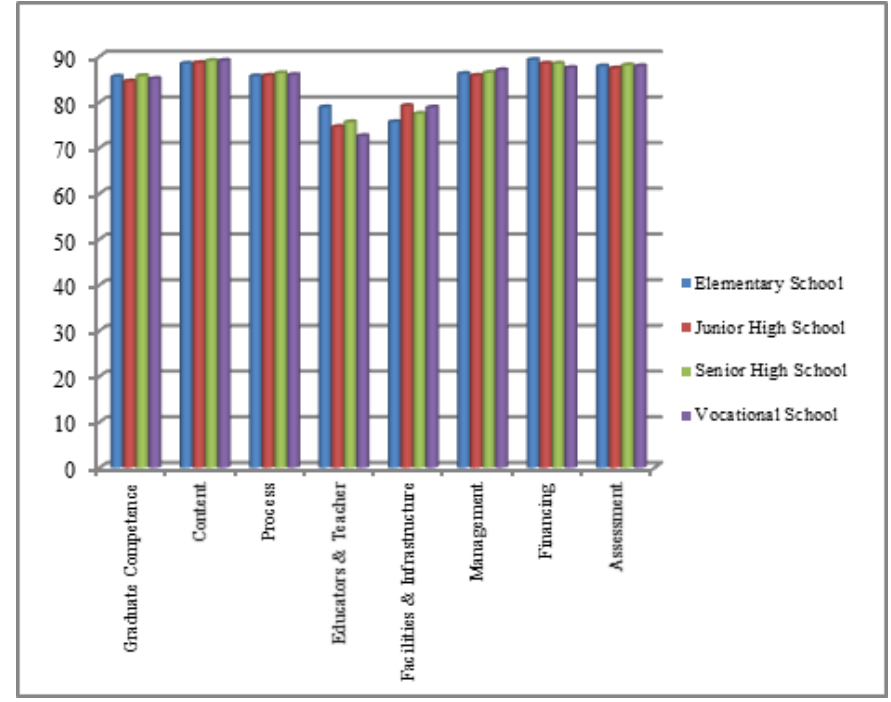

Fig. 6. Quality Report on each standard based on Accreditation [32].

Based on Figure 6, for the SD/MI level, the standard achievement of educators and educational staff is 78.92 (in 2019). There was an increase in the average standard achievement of educators and education personnel, namely 1.59 compared to 2014 with a score of 77.33. Even though it is increasing, the achievement of this standard is still low among other standards, especially for the achievements in 2019, after facilities and infrastructure. For the SMP/MTs level, there was a decrease of 1.39 and was at the lowest level among other standards in 2014 and 2019. The score obtained in 2014 was 76.00 while 2019 was 74.61. For the SMA/MA and SMK/MK levels, there was also a decline of 2.08 and 5.48 respectively. This decrease is quite significant compared to the level of basic education.

From the two-information presented above (internalexternal), some conclusions are consistent with internal and external evaluations which describe in general schools in Indonesia experiencing problems in the learning process. One of the causes is the competence of teachers that have not met national standards. Teachers are declared to meet the standards if they have four competencies, namely pedagogical, personal, social, and professional competencies obtained through professional education, as well as meeting the requirements according to the determined competency indicators. The four competencies are holistic and inherent in teachers in carrying out their profession [26]. The condition of this problem was found conically from the results of SSE and accreditation. So that it can be easily designed a quality compliance strategy for schools, local governments, and the central government, especially to meet the standards of educators and education personnel.

\section{DISCUSSION}

The practice of quality assurance of education that has developed in various countries is carried out with a combination of internal and external quality assurance. Internal 
quality assurance is carried out through school self-evaluation, and external quality assurance is carried out through accreditation. In some countries, such as the UK and the Netherlands, school self-evaluation results are used as the main reference for examiners, because self-evaluation can provide complete school and class reports [16,27]. In Indonesia, the quality report card results are used as a guide for assessors to assess the fulfill/comply of national education standards. Data available in school self-evaluations are used as external feedback for continuous quality assurance and improvement $[18,28]$.

The concepts used in internal quality assurance are generally an extension of the Plan-Do-Check-Act (PDCA) cycle $[10,29]$. As in Ireland, school self-evaluation uses six activity cycles, namely gather evidence, analyse evidence, make judgments, school SSE reports, school improvement plans, and monitor and implement [12,30]. China uses planning, doing, reflecting, and revising cycles [14]. Vietnam uses a cycle of planning, monitoring, evaluating, and implementing recommendations for continuous development [31]. Singapore uses a cycle of target setting, implementation, data collection, and evaluation and improvement [15]. Indonesia uses five cycles, namely school mapping, plan, implementation, monitoring and evaluation, and improvement [21]. All school self-evaluation cycles are carried out systematically and periodically.

School self-evaluation is a planned and continuous systematic process initiated by schools to collect actual information on school conditions. It aims to assess and measure the progress of education in schools as well as to be useful as a material for decision making for school development [32,33]

Many countries have laws and regulations requiring periodic external evaluation (inspection or accreditation) to be carried out. Although not many countries require periodic internal evaluation [34]. In Indonesia, internal and external evaluations are mandatory and conducted regularly and are regulated by laws and regulations. School self-evaluation is carried out annually, and accreditation is carried out once in five years. Meanwhile, the central and local governments provide assistance or facilitation for quality improvement.

\section{CONCLUSION}

School self-evaluation and accreditation use the same quality standards, namely the eight national education standards. Both of these evaluations are useful for helping schools to know the achievement of meeting national standards. School quality reports and accreditation scores are then used by the school to plan improvements and to fulfill/comply of quality. With the transformation of the concept and practice of internal quality assurance (SSE version 2016) the gap in accreditation assessment that has occurred so far has been able to be reduced. So that schools are more focused on efforts to improve priorities in meeting quality standards.

\section{ACKNOWLEDGMENT}

The author would like to thank Regional Agency for Quality Assurance on Education of Riau Islands Province, Ministry of Education and Culture (MoEC) for providing data and information. The author also thanks the Head of the Educational Administration Study Program, Postgraduate School of the Universitas Pendidikan Indonesia who has encouraged researchers to undertake studies

\section{REFERENCES}

[1] E. Garira, "Needs assessment for the development of educational interventions to improve quality of education: A case of Zimbabwean primary schools," Soc. Sci. Humanit. Open, vol. 2, no. 1, p. 100020 2020, doi: 10.1016/j.ssaho.2020.100020

[2] E. Garira, "A Proposed Unified Conceptual Framework for Quality of Education in Schools," SAGE Open, vol. 10, no. 1, 2020, doi: $10.1177 / 2158244019899445$.

[3] G. McNamara, J. O'Hara, P. L. Lisi, and S. Davidsdottir, "Operationalising self-evaluation in schools: Experiences from Ireland and Iceland," Irish Educ. Stud., vol. 30, no. 1, pp. 63-82, 2011, doi: 10.1080/03323315.2011.535977.

[4] D. Nevo, "Combining internal and external evaluation: A case for school-based evaluation," Stud. Educ. Eval., vol. 20, no. 1, pp. 87-98, 1994, doi: 10.1016/S0191-491X(00)80007-3.

[5] D. Nevo, "School evaluation: Internal or external?," Stud. Educ. Eval., vol. 27, no. 2, pp. 95-106, 2001, doi: 10.1016/S0191-491X(01)00016-5.

[6] D. Nevo, "Internal and external evaluation," Int. Encycl. Educ., pp. 781785, 2010, doi: 10.1016/B978-0-08-044894-7.01597-9.

[7] F. J. G. Janssens and G. H. W. C. H. van Amelsvoort, "School selfevaluations and school inspections in Europe: An exploratory study," Stud. Educ. Eval., vol. 34, no. 1, pp. 15-23, 2008, doi 10.1016/j.stueduc.2008.01.002.

[8] C. Leite, J. C. Morgado, and F. Seabra, "External School Evaluation in Portugal: a glance at the impacts on curricular and pedagogical practices,” Eur. J. Curric. Stud., vol. 1, no. 1, pp. 124-132, 2014.

[9] G. Devos and J. C. Verhoeven, "School Self-Evaluation-Conditions and Caveats," Educ. Manag. Adm., vol. 31, no. 4, pp. 403-420, 2003 , doi: $10.1177 / 0263211 \times 030314005$

[10] R. H. Hofman, N. J. Dijkstra, and W. H. Adriaan Hofman, "School selfevaluation and student achievement," Sch. Eff. Sch. Improv., vol. 20, no. 1, pp. 47-68, 2009, doi: 10.1080/09243450802664115.

[11] L. Croxford, S. Grek, and F.J. Shaik, "Quality assurance and evaluation (QAE) in Scotland: Promoting self-evaluation within and beyond the country," J. Educ. Policy, vol. 24, no. 2, pp. 179-193, 2009, doi: 10.1080/02680930902734095.

[12] S. O’Brien, G. McNamara, J. O’Hara, and M. Brown, "Irish teachers, starting on a journey of data use for school self-evaluation," Stud. Educ Eval., vol. 60, no. January 2018, pp. 1-13, 2019, doi: 10.1016/j.stueduc.2018.11.001.

[13] G. Kurum and S. Cinkir, "An authentic look at evaluation in education: A school self-evaluation1 model supporting school development," Eurasian J. Educ. Res., vol. 2019, no. 83, pp. 253-286, 2019, doi: 10.14689/ejer.2019.83.12

[14] H. Chen, Y. Su, Q. Zheng, and L. Li, "Towards an operationalized and effective school self-evaluation system: An ongoing action research study in Chinese secondary schools since 2011," Stud. Educ. Eval., vol 60, no. January, pp. 117-129, 2019, doi: 10.1016/j.stueduc.2018.12.005.

[15] J. Huang, Y. Tang, W. He, and Q. Li, "Singapore's School Excellence Model and student learning: evidence from PISA 2012 and TALIS 2013," Asia Pacific J. Educ., vol. 39, no. 1, pp. 96-112, 2019, doi: 10.1080/02188791.2019.1575185. 
[16] C. Chapman and P. Earley, "School inspection/external school evaluation," Int. Encycl. Educ., pp. 719-725, 2010, doi: 10.1016/B9780-08-044894-7.01620-1.

[17] B.T. Hinnerich and J. Vlachos, "The impact of upper-secondary voucher school attendance on student achievement. Swedish evidence using external and internal evaluations," Labour Econ., vol. 47, no. March, pp. 1-14, 2017, doi: 10.1016/j.labeco.2017.03.009.

[18] S.I. Hofer, D. Holzberger, and K. Reiss, "Evaluating school inspection effectiveness: A systematic research synthesis on 30 years of international research," Stud. Educ. Eval., vol. 65, no. March, p. 100864, 2020, doi: 10.1016/j.stueduc.2020.100864.

[19] J. Vanhoof and P. Van Petegem, "Evaluating the quality of selfevaluations: The (mis)match between internal and external metaevaluation," Stud. Educ. Eval., vol. 36, no. 1-2, pp. 20-26, 2010, doi: 10.1016/j.stueduc.2010.10.001.

[20] J. Vanhoof and P. Van Petegem, "Matching Internal and External Evaluation in an Era of Accountability and School Development: Lessons From a Flemish Perspective,” Stud. Educ. Eval., vol. 33, no. 2, pp. 101-119, 2007, doi: 10.1016/j.stueduc.2007.04.001.

[21] Permendikbud Nomor 28 Tahun 2016, "Sistem Penjaminan Mutu Pendidikan Dasar dan Menengah,” Kemdikbud, 2016.

[22] D. Meirawan, "Penjaminan Mutu Satuan Pendidikan Sebagai Upaya Pengendalian Mutu Pendidikan Secara Nasional dalam Otonomi Pendidikan,” Educationist, vol. IV, no. 2, pp. 126-137, 2010.

[23] V. Basili et al., "B Ridging the G Ap Between B Usiness S Trategy and," Twenty Eight Int. Conf. Inf. Syst., vol. 85, no. November, pp. $1-$ 16, 2007.

[24] E.A. Hanushek and S.G. Rivkin, "Chapter 18 Teacher Quality," Handb. Econ. Educ., vol. 2, no. 06, pp. 1051-1078, 2006, doi: 10.1016/S15740692(06)02018-6.
[25] I. Dekawati, A. Komariah, A. Mulyana, D. A. Kurniady, A. Kurniawan, and S. H. Salsabil, "The role of instructional leadership on school quality through school climate as a mediator," Talent Dev. Excell., vol. 12, no. SpecialIssue3, pp. 1176-1187, 2020.

[26] Government of the Republic of Indonesia, "Peraturan Pemerintah Republik Indonesia Nomor 19 Tahun 2017 tentang Perubahan atas Peraturan Pemerintah Republik Indonesia Nomor 74 Tahun 2008 tentang Guru," 2008.

[27] K. Schildkamp, J. Vanhoof, P. Van Petegem, and A. Visscher, "The use of school self-evaluation results in the Netherlands and Flanders," Br. Educ. Res. J., vol. 38, no. 1, pp. 125-152, 2012, doi: 10.1080/01411926.2010.528556.

[28] F. Authors, School-Based Evaluation: An International Perspective Article information : 2015.

[29] R. Nelson, M. Ehren, and D. Godfrey, "Literature Review on Internal Evaluation," vol. 44, no. September, pp. 1-76, 2015.

[30] S. O’Brien, G. McNamara, J. O'Hara, and M. Brown, "External specialist support for school self-evaluation: Testing a model of support in Irish post-primary schools," Evaluation, vol. 23, no. 1, pp. 61-79, 2017, doi: $10.1177 / 1356389016684248$.

[31] T.P.L. Nguyen, "Quality assurance and accreditation in upper secondary schools in Hatinh province in Vietnam," 2015.

[32] K. Schildkamp and A. Visscher, "Factors influencing the utilisation of a school self-evaluation instrument," Stud. Educ. Eval., vol. 35, no. 4, pp. 150-159, 2009, doi: 10.1016/j.stueduc.2009.12.001.

[33] K. Schildkamp and A. Visscher, "The utilisation of a school selfevaluation instrument," Educ. Stud., vol. 36, no. 4, pp. 371-389, 2010, doi: 10.1080/03055690903424741.

[34] Annex A. The OECD Review on Evaluation and Assessment Frameworks for Improving School Outcomes," no. March, pp. 213-214, 2012, doi: 10.1787/9789264172647-11-en 